\title{
Academic Supervision Management to Improve the Quality of Mathematics Learning in Madrasah Aliyah
}

\author{
${ }^{*}$ Raudlatul Munawarah ${ }^{1}$, Dadang Suherman ${ }^{2}$, Waska Warta ${ }^{3}$, R. Supyan Sauri ${ }^{4}$ \\ ${ }^{1,2,3,4}$ Universitas Islam Nusantara, Jl. Soekarno-Hatta No.530, West Java, Indonesia \\ *raudlatulmunawarah@gmail.com
}

\begin{abstract}
Academic supervision is the duties and responsibilities of academic supervisors, which the Principal/Madrasah can also carry out. This supervision activity can be delegated to more senior teachers who are concerned as coaches, so they are supervisors in carrying out their duties. However, the person concerned must still report the results of academic supervision activities to the principal/madrasah. The quality of learning can be said to be a picture of the good and bad results achieved by students in the learning process. Schools are considered quality if they change students' attitudes, behaviour, and skills about their educational goals. This study uses a qualitative method. In essence, there are many variations of management functions, Planning, Organizing and Staffing, Leading, Controlling. To support the realization of excellent madrasas, several roles of excellent teachers must be carried out. There are three duties as a profession, namely educating, teaching, and training. It is not enough to cram subject matter to students as a teacher.
\end{abstract}

Keywords: Academic Supervising Management, Quality of Mathematics Learning, Madrasah Aliyah.

\section{Introduction}

As formal educational institutions that organize learning activities, Madrasas require quality human resources for the success of the madrasa. The success of an educational institution in carrying out its mission is primarily determined by improving the quality of the work of educational institutions, such as academic staff, facilities and infrastructure, costs, students, the community and the supportive environment. Academic staff is one essential element to improve the quality of learning both general subjects and religious learning in Madrasah Aliyah educational institutions in particular (Rasyidi, 2019).

Teachers as human resources have a vital role in schools/madrasas (Hardiyanto, 2020). As teachers, mentors and facilitators in learning activities, teachers must shape student behaviour and assist in solving problems students face in life (Andreasen, Bjørndal, \& Kovač, 2019). Teachers directly interact with 
students, a substantial contribution to supporting student learning success. The ability of teachers to manage the teaching and learning process can encourage students to develop their potential. Competent teachers will produce high performance, create an effective learning environment, and better manage the class so that student learning outcomes will be more optimal (Helleve, Grov Almås, \& Bjørkelo, 2020).

Madrasas are schools that are organized and under the coordination of the Ministry of Religion. As stated by Rahardjo, H.M., the uniqueness of the specificity of the madrasa educational institution is because of the values of sincerity, blessing, tawadu', istiqomah, ijtihad and so on (Mustafa, Rezaur, Rahardjo, \& Isa, 2014). Substantially, the difference between madrasas and public schools is that madrasas are public schools with Islamic characteristics (Ikhwan, 2019). These characteristics are in the form of 1) Religious subjects that are translated from Islamic religious education, namely the Qur'an Al Hadith, Aqidah Akhlak, Fiqh, Islamic Cultural History, and Arabic, 2) Religious atmosphere, which is an atmosphere of madrasa life religion, the existence of religious facilities, the use of a religious approach method in the presentation of learning materials for every possible subject, and the qualifications of teachers who must be Muslim and have a noble character, in addition to meeting qualifications as teaching staff based on applicable regulations (Mahmud, 2019).

\section{Theoretical Framework}

the idea of Academic Supervision Management, Teacher Ability Development, and Learning Quality. Academic supervision is a series of activities to assist teachers in developing their ability to manage the learning process to achieve educational goals. The development of teacher competence is a process of changing teachers' professional skills in stages towards the better for the creation of perfection (Ikhwan, Farid, Rohmad, \& Syam, 2020).

The quality of learning can be said to describe the good and bad results achieved by students in the learning process carried out. Schools are considered quality if they succeed in changing students' attitudes, behaviour, and skills related to their educational goals. 


\section{Method}

The research method used is qualitative. This method is very accurate because it explains the facts in the field. It is expected to find solutions to problems related to Student Center Learning Management (SCL) in improving students Soft Skill and Hard Skill competencies (Ikhwan, 2021). Sukmadinata explains that "research with qualitative methods is intended to describe or describe existing phenomena, both natural phenomena or human engineering." (Sukmadinata, 2008).

\section{Result and Discussion}

\section{Academic Supervision Management Concept}

According to Massie and Douglas, "a process when a group of people work together to direct others to work towards the same goal" (Massie, 1986). Management, according to Kreitner, is "a process of working together with and through others to achieve organizational goals effectively and efficiently using limited resources in a changing environment" (Kreitner, 2010). Management, according to Sisk, Henry. L, "coordination of all resources through the process of planning, organizing, directing, and controlling to achieve certain specified goals" (Sisk, 1969).

At its core, there are many variations of the management function. It starts from the simple, namely three parts, to five positions. The following sections further explain each of these management functions.

\section{Planning}

Planning means setting organizational goals and choosing the best way to achieve those goals. Decision making is part of planning which means determining or selecting an alternative to achieve goals from several available options. Planning is needed to direct the activities of the organization. In the first step, a plan is established for the organization. Then, a more detailed plan for each section or division is based. In this way, the organization has a consistent overall plan.

Some of the benefits of planning are (1) directing organizational activities, which include the use of resources and their use to achieve organizational goals, (2) strengthening the consistency of organizational members' activities so that they are by organizational goals, and (3) monitoring organizational progress. If the organization deviates from the goals that have been set, improvements can be made. 
The third benefit is closely related to control activities. Control requires planning, and planning is beneficial to control.

\section{Organizing and Staffing}

The next stage is organizing. Organizing can be defined as coordinating resources, tasks, and authority among members of the organization so that organizational goals can be achieved efficiently and effectively. For example, most company activities are organized around the company's core functions, such as marketing, finance, production, administration, and personnel. Each is grouped into its department or section. Each section is headed by a manager who reports to the president director.

\section{Leading}

Once the organizational structure is established, the people are defined. The next step is to create how these people work to achieve organizational goals. Managers need to "direct" these people. More specifically, direction includes the activities of giving advice (directing), influencing others (influencing), and motivating the person to work (motivating). Leading is usually the most challenging and crucial management activity because it deals directly with humans.

\section{Controlling}

The final element of the management process control. Control aims to see whether the organization's activities are by the plan. Managers must constantly monitor the progress of the organization. The control function includes four activities: (1) determining the standard of achievement, (2) measuring the achievements that have been achieved so far, (3) comparing the achievements that have been achieved with the achievement standards, and (4) making improvements if there are deviations from the achievement standards that have been set. Then, back to the planning function for the next period.

Meanwhile, according to Fayol, the principles of effective management practice can be seen (Wood \& Wood, 2002);

a. Division of labour: specialization makes work more efficient. The assembly line is an example of discipline.

b. Authority: the manager must give orders to be carried out. Formal authority grants the right to govern, but personal reference must also be attained for the command to be more effective. An example of personal power is the expertise possessed by a manager or knowledge that exceeds his employees' ability. 
c. Discipline: members of the organization must comply with the rules and agreements that govern the organization. Discipline results from good leadership at every level of the organization, fair contracts (e.g. achievements will be rewarded more), and violations.

d. Unity of command: each team member only receives instructions from one superior. If employees have multiple bosses, conflict and chaos will occur.

e. Unity of direction: activities in an organization with the same goal should be directed by only one manager using a single plan.

f. Individual interests must be subordinate to the organisation's interests: individual interests must not overcome the interests of the organization.

g. Payroll: the payroll system should be fair, both for managers and employees.

h. Centralization: the manager is responsible for his organization (because he can give orders to employees), but at the same time, employees must be given sufficient authority to carry out their work. Thus, optimal levels of centralization and decentralization should be sought.

i. Hierarchy: the line of authority in the organization descends from top managers to lower-level employees.

j. Command: resources (material and human) must be coordinated so that they are always ready at the time and place needed.

k. Similarities: managers must be fair in treating employees and friendly with employees.

1. Staff stability: high turnover should be avoided as it makes the organization inefficient.

m. Initiative: employees are given the freedom to take the initiative to do work.

The implementation of academic supervision begins with conducting a needs analysis by identifying the coaching results that have been done previously. Then an assessment and monitoring are carried out in the form of Continuous Professional Development activities.

The main problem faced in supervision in the educational environment is changing autocratic and corrective behaviour into 
constructive and creative behaviour. The attitude of openness and prioritizing positive human relations from a supervisor will arouse the desire and sincerity of the teacher to improve or develop his professionalism by the demands of his duties. And build teacher achievement requires feedback from the supervisor. Feedback is in the form of information or data about their behaviour and performance.

According to Danim \& Khairil, the principles of supervision are as follows (Danim \& Khairil, 2012);

a. Supervision gives a sense of security to the supervised party.

b. Supervision is constructive and creative.

c. Supervision is realistic based on the actual situation and reality.

d. The implementation of supervision activities is simple because it does not complicate the process, interfere with the teacher's duties, and even give birth to frustration. 5. During the implementation of supervision, a professional relationship is established, not based on a personal relationship.

e. Supervision is based on the supervised party's ability, ability, condition, and attitude.

f. Supervision helps teachers continually grow on their own, not depending on school administrators.

g. Supervision provides guidance and assistance to teachers and other school staff to overcome problems and difficulties and not find fault.

h. The provision of assistance and guidance is carried out directly. Those who receive help and advice are not forced, but their hearts are opened to feel alone and commensurate with their ability to cope on their own.

i. Suggestions or feedback from supervisors to teachers are submitted as soon as possible.

j. Supervisors provide opportunities for supervised teachers to ask questions or respond.

k. Supervision activities are carried out periodically, not according to the interests and opportunities of the supervisor.

1. The atmosphere that occurs during supervision reflects a good relationship between the supervisor and the supervised, in the form of an intimate partnership atmosphere. 
m. Supervised teachers openly express opinions about the difficulties they face or their shortcomings.

n. All supervision documents are presented in writing and well documented.

o. Supervision documents in the form of images are stored properly.

Academic supervision is intended to help teachers improve learning so that, in the end, it can enhance student learning. By these objectives, the term that is often used is instructional supervision. There are various techniques of academic supervision to develop teacher abilities. This includes staff meetings, supervision visits, professional bulletins, professional libraries, curriculum laboratories, teacher assessments, learning demonstrations, curriculum development, and development of learning guides, field trips, workshops, class visits, professional reading, and school-community surveys (Syam, 2017).

Meanwhile, according to Gwyn, the supervision techniques can be grouped into two groups, namely. Individual supervision techniques and group supervision techniques.

1. Individual Supervision Techniques

The individual supervision technique here is the implementation of supervision given to particular teachers who have unique and personal problems. The supervisor here only deals with a teacher who has specific issues.

\section{Group Supervision Techniques}

The group supervision technique is implementing a supervision program aimed at two or more people. According to the needs analysis, teachers suspected of having the same problems or needs or weaknesses are grouped or grouped. Then they are given supervision services according to the issues or needs they face.

\section{Steps to Build Teacher Ability}

There are five steps to developing teacher abilities through academic supervision, namely: (1) creating harmonious relationships, (2) needs analysis, (3) developing strategies and media, (4) assessing, and (5) revising.

The first step in fostering teacher learning skills is to create a harmonious relationship between supervisors and teachers and all parties related to the teacher learning skills development program. To carry out academic supervision, it is necessary to clarify information 
between the relevant personnel. Without clarity of communication, teachers will be confused, do not know what the principal expects, and believe that the main goal in measuring teacher abilities, as the first step in developing learning skills through academic supervision, is only to identify good teachers and those who are less skilled in teaching. If there is clarity of information, of course, there will not be such a teacher.

Communication between the principal and the teacher is said to be effective if the teacher accepts academic supervision to develop his abilities. In this effort, it is necessary to clarify information regarding the nature and purpose of educational leadership. In an attempt to explain the academic supervision program, we need a certain way and principles in communicating.

How to communicate effectively. There are several communication principles that school principals must apply, as stated by Marks, Stoops and Stoops (Marks, Stoops, \& King, 1985), as follows:

a. Speak wisely and as best you can

b. Follow other people's conversations carefully

c. Create interpersonal relationships between personnel

d. Think before you speak

e. Follow the norms that apply in the school setting

f. Try to understand the opinions of others

g. Concentrate on your message, not on yourself

h. Gather materials for discussion if necessary

i. Keep the conversation short

j. Create impotence

k. Get excited

1. Get the attitude of others to help the program

m. Communicate with "eye communication"

n. Always try

o. Be a good listener 


\section{Learning Quality Concept}

In general, the definition of quality, according to several experts, is in Suardi. R. (Suardi, 2004);

a. Philip B. Crosby argues that quality means conformance to requirements, such as a waterproof watch, durable shoes or a skilled doctor. He also emphasized the importance of involving everyone in the processes in the organization'.

b. Deming $\mathrm{E}$ argues that quality means problem-solving to achieve continuous improvement.

c. Joseph M. Juran Juran argues that quality means fit for use, such as shoes designed for sports or leather shoes designed for the office. Juran's approach is oriented towards meeting customer expectations.

School quality is determined by three variables: school culture, teaching and learning process, and school reality. School culture is the values, habits, ceremonies, slogans, and various behaviours that have long been formed in schools and passed on from one generation to the next, whether consciously or not. This culture is believed to influence the behaviour of all components of the school, namely teachers, principals, administrative staff, students, and parents. A culture conducive to quality improvement will encourage residents' behaviour towards improving the quality of schools. Otherwise, a not conducive culture will hinder efforts to enhance the quality of the school.

To realize a quality learning process, the government issued Government Regulation No. 19 of 2005 concerning National Education Standards (SNP) to elaborate further on the National Education System Law, which contains process standards. About quality learning, Pudji, M., states that the concept of learning quality contains five references, namely (Muljono, 2006):

a. Suitability includes the following indicators: commensurate with the characteristics of students, in line with the aspirations of the community and individuals, by the needs of the community, by environmental conditions, by the demands of the times, and by new theories, principles, and values in education.

b. Quality learning must also have a strong appeal. The indicators include learning opportunities that are scattered and therefore easy to achieve and follow, educational content that is easy to digest because it has been processed in such a way, available 
opportunities that anyone can obtain at any time needed, messages were given at the right time and event, high reliability, mainly because of the outstanding performance of the institution and its graduates, the diversity of sources both intentionally developed and those that are already available and can be selected and utilized for learning purposes, and a warm, friendly atmosphere and stimulate the formation of the personality of students.

c. The effectiveness of learning is often measured by the achievement of goals or can also be interpreted as accuracy in managing a situation or "doing the right things". This definition contains characteristics: systematic (systematic), which is carried out regularly, consistently or sequentially through the stages of planning, development, implementation, assessment and refinement, sensitivity to the need for learning tasks and learning needs, clarity of goals, and therefore efforts can be gathered to achieve it, starting from the ability or strength of those concerned (students, educators, society and government).

Learning efficiency can be defined as the equivalence between the time, cost, and energy used with the results obtained or can be said to be doing something right. The characteristics contained include designing learning activities based on models referring to the interests, needs, conditions of students, organizing neat learning and learning activities, for example, paying attention to the environment or background, utilizing various resources with a balanced division of tasks, as well as developing and using multiple learning resources according to their needs. Needs, the use of shared learning resources, innovative savings efforts, such as distance learning and open learning that do not require building construction and hiring educators who are paid regularly. The essence of efficiency is to develop various internal and external (systemic) factors to develop alternative actions and then choose the most profitable action.

\section{Mathematics Teacher Professionalism}

Professional teachers should have four teacher competencies that have been stipulated in the Law of the Republic of Indonesia Number 14 of 2005 concerning Teachers and Lecturers, namely, pedagogic, personality, professional and social competencies (Depdiknas, 2005). Therefore, besides being skilled at teaching, a teacher also has extensive knowledge, is wise, and can socialize well. Of course, we also want to become professional teachers, but many criteria must be met to become an experienced teachers. The criteria include: 
a. Having noble character and character so as to be able to set a good example for students.

b. Have the ability to educate and teach students well.

c. Mastering the material or subject matter that will be taught in teaching and learning interactions

d. Have academic qualifications and educational background according to the field of work.

e. Mastering various educational administrations (RPP, Syllabus, Curriculum, KKM, and so on)

f. Have high enthusiasm and motivation to devote their knowledge to students.

g. Never stop to learn and develop his abilities.

h. Participate in training and training to add insight and experience.

i. Active, creative, and innovative to develop learning and always up to date on information or problems that occur around.

j. Mastering science and technology (computers, internet, blogs, facebook, websites, etc.).

k. Likes to read as an effort to explore and add insight.

1. Never stop working (making CAR, teaching materials, articles, etc.)

m. Able to interact and socialize with parents, peers and the surrounding environment well.

n. Active in the activities of educational organizations (KKG, PGRI, Scouts)

o. Have an attitude of love, sincere and sincere in teaching

Various efforts to improve teacher professionalism have been taken by the government, educational institutions, and teachers. The steps to improve it are as follows:

1. Take education at a higher level according to academic qualifications

This is based on the Lecturer Teacher Law that teachers must go through professional education to gain professional competence. Teachers are also required to have a minimum academic qualification of S-1 or D4. Especially at this time, the development of the world of education and the education system is increasing. By continuing the 
level of education, it is hoped that the teacher can increase his knowledge and obtain new information in education so that the teacher knows the development of educational science.

\section{Through the Teacher Certification Program}

One of the efforts to improve teacher professionalism is through certification, where certification is reflected in the existence of a fit and proper test that a person must undergo, against the criteria that have been ideally set. The accreditation will spur the spirit of teachers to improve themselves, improve the quality of knowledge, and professionalism in the world of education.

3. Provide education and training for teachers

Training and training are coaching techniques to add insight/knowledge to teachers. Education and training activities need to be carried out by the teacher with follow-up efforts to implement the training and training results.

\section{Reading Teacher Movement (G2M)}

Teachers should be aware of the importance of reading to develop their insight and knowledge. It's not funny if the teacher tells the students to read diligently while they are reluctant to read. We, as teachers, must know more than students. For this reason, it is necessary to encourage the Reading Teacher Movement. In this case, the teacher can take advantage of books or mass media available in libraries, schools, or bookstores. It can also access the internet about matters related to their specialization or general knowledge that can increase their knowledge.

5. hrough the KKG (Teacher Working Group) organization

One of the forums or places that can foster and improve elementary school teachers' professionalism is the KKG. The KKG is a forum for teacher-teacher collaboration and as a place to discuss problems related to professional abilities, namely in planning, implementing and assessing student progress.

6. Always be productive in producing works in the field of education.

Teachers should be aware of writing more, especially on educational and teaching issues. This is one of the methods to improve the teacher's ability to express concepts and ideas in written form. 
One of the subjects considered very important in the world of education in Indonesia in all educational institutions, including madrasas, is mathematics. Mathematics is a universal science and underlies the development of modern science and technology, advancing human thinking and analysis. Mathematics is classified as an abstract subject. Therefore, the learning process requires serious attention from all parties, such as teachers, the school environment, guardians of students, and the playing environment at home. Learning mathematics is a process in which students actively construct mathematical knowledge (Suherman, 2003). The role of some of these parties dramatically affects the success of learning mathematics.

Starting from elementary school, mathematics subjects have been given to all students. This is to equip students with the competence to think logically, analytically, systematically, critically, innovatively and creatively, and the ability to work together. These competencies are needed so that students can have the ability to obtain, manage, and utilize information to live better in conditions that are constantly changing, uncertain, and highly competitive. For this, the teacher's role is very dominant because it is the teacher who best knows the condition of the class, how the students are in attending the course, what the teacher's ability is, and even how appropriate the existing infrastructure is.

Nowadays, becoming a math teacher is more accessible in terms of facilities than in the 90 s and below. However, considering that mathematics is an abstract science according to most people, an educator, in carrying out mathematics learning, must be able to foster a sense of the importance of learning mathematics because learning mathematics is related to what and how to use it in making decisions to solve problems.

\section{Conclusion}

Educational institutions always strive to make their madrasas superior madrasas. Superior madrasas, commonly called effective schools, show that Islamic educational institutions have opened themselves up and are accommodating to the aspirations and demands of the community, as well as one form of government steps in developing educational institutions. With time, it is undeniable that superior madrasas have become a trend among the community because they offer many advantages in academic and non-academic fields. 
Superior madrasas always prioritize added value that must be given to students after attending education at the school. This added value makes teaching effective. Excellent schools are identical to effective schools. Low-quality input will be processed optimally according to students' potential so that the output produced will have superior quality.

There are several prominent teacher roles to be carried out to support the realisation of superior madrasah. There are three duties of teachers as a profession: educating, teaching, and training. It is not enough to cram subject matter to students as a teacher. The definition of educating is to continue and develop the values of life, while teaching is to continue and build knowledge.

Through academic supervision activities carried out by supervisors, it is hoped that not only the knowledge and skills of teachers will improve, but there will also be an increase in the willingness, commitment and motivation of the teachers.

\section{Bibliography}

Andreasen, J. K., Bjørndal, C. R. P., \& Kovač, V. B. (2019). Being a teacher and teacher educator: The antecedents of teacher educator identity among mentor teachers. Teaching and Teacher Education. https://doi.org/10.1016/j.tate.2019.05.011

Danim, S., \& Khairil. (2012). Profesi Kependidikan. Bandung: Alfabeta.

Depdiknas. (2005). Undang-undang Nomor 14 Tahun 2005 Tentang Guru dan Dosen. Jakarta: Depdiknas RI.

Hardiyanto, F. E. (2020). Revitalizing the Prophetic Teacher Ethic in Developing Human Resources for Education. Universal Journal of Educational Research. https://doi.org/10.13189/ujer.2020.080653

Helleve, I., Grov Almås, A., \& Bjørkelo, B. (2020). Becoming a professional digital competent teacher. Professional Development in Education. https://doi.org/10.1080/19415257.2019.1585381

Ikhwan, A. (2019). Public Relations in an Islamic Perspective; Implementation Study at Madrasah. At-Turats: Jurnal Pemikiran Pendidikan Islam, 13(2), 105-117. https://doi.org/https://doi.org/10.24260/at-turats.v13i2.996

Ikhwan, A. (2021). Metode Penelitian Dasar (Mengenal Model Penelitian 
dan Sistematikanya). Tulungagung: STAI Muhammadiyah Tulungagung.

Ikhwan, A., Farid, M., Rohmad, A., \& Syam, A. R. (2020). Revitalization of Islamic Education Teachers in the Development of Student Personality. In 1st Borobudur International Symposium on Humanities, Economics and Social Sciences (BIS-HESS 2019) (pp. 162-165).

Kreitner, K. (2010). Organizational Behavior. New York: McGraw-Hill Book Co.

Mahmud. (2019). Pemikiran Pendidikan Islam. A Psicanalise Dos Contos de Fadas. Tradução Arlene Caetano.

Marks, J. R., Stoops, E., \& King, J. (1985). Handbook of educational supervision : a guide for the practitioner. Boston: Allyn and Bacon.

Massie, J. (1986). Dasar-Dasar Manajemen. Jakarta: Erlangga.

Muljono, P. (2006). Standar Proses Pembelajaran. Jakarta: Buletin BSNP.

Mustafa, M. R., Rezaur, R. B., Rahardjo, H., \& Isa, M. H. (2014). Closure to "Evaluation of MLP-ANN Training Algorithms for Modeling Soil Pore-Water Pressure Responses to Rainfall” by M. R. Mustafa, R. B. Rezaur, S. Saiedi, H. Rahardjo, and M. H. Isa. Journal of Hydrologic Engineering. https://doi.org/10.1061/(asce)he.1943-5584.0000974

Rasyidi, M. (2019). INOVASI KURIKULUM DI MADRASAH ALIYAH. Al Qalam: Jurnal Ilmiah Keagamaan Dan Kemasyarakatan. https://doi.org/10.35931/aq.v0i0.106

Sisk, H. L. (1969). Principles Of Management. Cincinnati: SouthWestern Publishing Company.

Suardi, R. (2004). Sistem Manajemen Mutu. Jakarta: Penerbit PPM.

Suherman, E. (2003). Strategi Pembelajaran Matematika Kontemporer. Bandung: PT Remaja Rosdakarya.

Sukmadinata, N. S. (2008). Metode Penelitian Pendidikan. Bandung: PT. Remaja Rosdakarya.

Syam, A. R. (2017). Posisi Manajemen Kurikulum Dan Pembelajaran Dalam Pendidikan. Muaddib: Studi Kependidikan Dan Keislaman, 7(1), 33-46.

Wood, J. C., \& Wood, M. C. (2002). Henri Fayol: Critical Evaluations in Business and Management. Britania Raya: Taylor \& Francis. 